\title{
NON-MARINE INVERTEBRATE TRACE FOSSILS FROM THE TERTIARY CALATAYUD-TERUEL BASIN, NE SPAIN
}

\author{
Alfred UCHMAN' and J. Javier ÁLVARO \\ ' Institute of Geological Sciences, Jagiellonian University, Oleandry 2a. PL-30-
63 Krakow, Poland.
' UPRESA 8014 CNRS, Cité Scientifique SN5, USTL. F-59655 Villeneuve
d'Ascq, France.
}

Uchman, A. and Álvaro, J.J. 2000. Non-marine invertebrate trace fossils from the Tertiary Calatayud-Teruel basin, NE Spain. [Icnofósiles realizados por invertebrados continentales en la cuenca terciaria de CalatayudTeruel, NE España]. Revista Española de Paleontología, 15(2), 203-218. ISSN 0213-6937.

\begin{abstract}
Relatively diverse trace fossils made by insects, other arthropods and oligochaete worms occur in the Miocene lacustrine and marginal lacustrine deposits of the Calatayud-Teruel basin (NE Spain). They include the ichnospecies Celliforma isp., Celliforma? isp. A and B, Celliforma? aff. habari, Rosellichnus cf. arabicus, Spongeliomorpha isp., Labyrintichnus terrerensis n. igen. et isp., Taenidium barreti, Beaconites filiformis n. isp. and Polykladichnus aragonensis n. isp. Their taxonomic and ethologic interpretations and cross-cutting relationships permit to envisage new lines of evidence for reconstructing transitions from dry-ground terrestrial to moist-ground and subaqueous environments, related to episodic floodings in lacustrine ponds. These environmental transitions (related to external controls) are characterized by benthic community replacements, evinced by vertical successions of Termitichnus, Scoyenia and Mermia-like ichnofacies.
\end{abstract}

Keywords: Trace fossils, ichnofacies, lacustrine deposits, Miocene, Spain.

\section{RESUMEN}

En los depósitos lacustres del Mioceno de la depresión de Calatayud-Teruel (NE España) se ha reconocido una amplia diversidad de icnofósiles realizados por insectos, otros artrópodos y gusanos poliquetos. Se han determinado las siguientes icnoespecies: Celliforma isp., Celliforma ? isp. A y B, cf. Celliforma ? aff. habari, Rosellichnus cf. arabicus, Spongeliomorpha isp., Labyrintichnus terrerensis n. igen. et isp., Taenidium barreti, Beaconites filiformis $\mathrm{n}$. isp. y Polykladichnus aragonensis n. isp. Su afinidad taxonómica y etológica, junto a las relaciones geométricas que conservan entre ellos, permiten aportar nuevas informaciones sobre los procesos biogénicos registrados en los medios sedimentarios lacustres. Éstos se caracterizan por variaciones graduales relacionadas con las inundaciones episódicas del sustrato lacustre y su consecuente desecación: desde los medios claramente subacuáticos a los parcialmente encharcados que finalizan en exposiciones subaéreas. Dicha transición, influenciada por controles externos, se caracteriza por la presencia de reemplazamientos de comunidades bentónicas, reflejadas por la sucesión vertical de las icnofacies de tipo Termitichnus, Scoyenia y Mermia.

Palabras clave: Pistas fósiles, icnofacies, depósitos lacustres, Mioceno, España.

\section{INTRODUCTION}

Non-marine paleoichnology has experienced a quick development during the last decade. It became clear that trace fossils can be helpful to determine some environmental parameters in non-marine settings, similarly to the proposals envisaged in marine environments (Hasiotis and Bown, 1992; Donovan, 1994; Buatois and Mángano, 1995, 1998). Unfortunately, recognition of trace fossils and ichnofabrics in non-marine depositional systems is commonly very incomplete. For this reason, each contribution on this topic is a small step towards new reappraisals of the problem.

A relatively rich assemblage of trace fossils has been found in the Miocene non-marine, lacustrine deposits of the Calatayud-Teruel basin (NE Spain). The aim of this paper is the description and interpretation of the trace fossils and ichnofacies found at the locality of Terrer (Fig. 1), as a tool for interpreting indicators of palaeoenvironmental changes. 


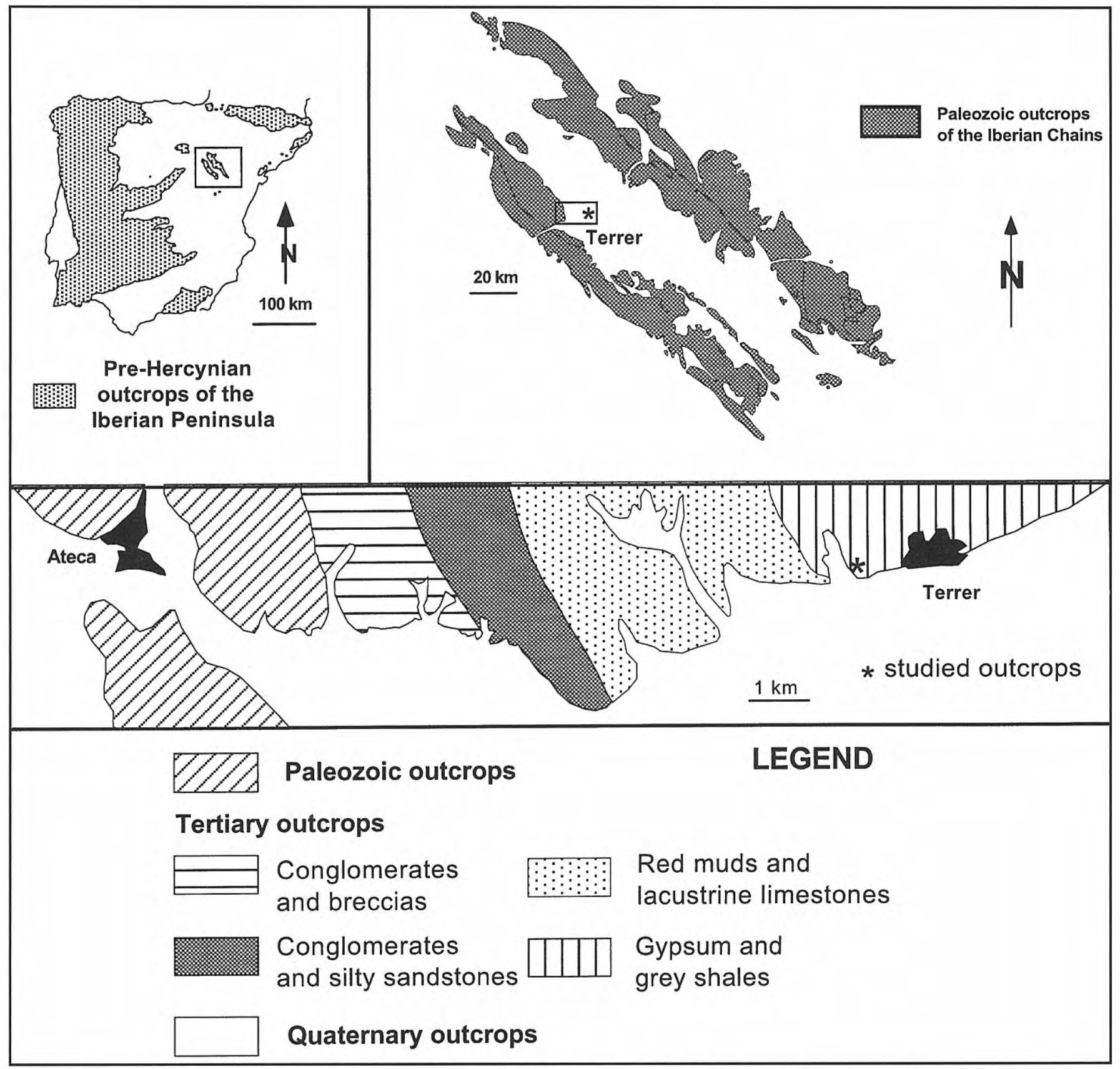

Figure 1. Geologic sketch of the Calatayud-Teruel basin in the NE of the Iberian Peninsula.

Ichnological research of Tertiary continental evaporite successions in Spain, including the Calatayud-Teruel basin, has been previously carried out by RodríguezAranda (1992) and Rodríguez-Aranda and Calvo (1998). The latter authors recognized small and large rhizoliths, 'tangle-patterned small burrows', 'isolated large burrows', 'L-shaped traces' and vertebrate tracks.

\section{GEOLOGIC SETTING AND STRATIGRAPHY}

The Tertiary Calatayud-Teruel basin exhibits a NWSE-trending pattern in NE Spain. It cuts longitudinally the Paleozoic and Mesozoic outcrops of the Iberian
Ranges, dividing them into the western and eastern Iberian chains. The basin consists of a mosaic of troughs with different tectonostratigraphic evolution. Our study is focused in the western margin of the Calatayud subbasin, in the outcrops bounding the locality of Terrer (Fig. 1), which are equidistant from the Paleozoic rocks of the western Iberian chain and the Tertiary Calatayud depocenter. From a lithostratigraphic point of view, the fill of the Calatayud sub-basin shows a distinct lateral change, from conglomerates and breccias near the Paleozoic border to alternating gypsum and marls in its depocenter. In its middle part, a belt composed of brownish shales and gypsum crops out parallel to the Paleozoic margin. This lithostratigraphic unit, named "Gypsum and grey shales" by Olmo et al. (1983), 
consists of brownish to grey shales ( 0.2 to $20 \mathrm{~m}$ thick) alternating with gypsum beds up to $0.5 \mathrm{~m}$ thick, and with isolated green, sandy marlstones at the bottom.

An upward increase of gypsum beds is recognized in this lithostratigraphic unit throughout the geomorphologic "mesetas" of the area; hence, the lower part of the formation records the better conditions to contain trace fossils. The age of these deposits is Aragonian to Vallesian (Miocene) based on the occurrence of vertebrate remains (Crusafont et al., 1966). We have studied the western outcrops of the "Gypsum and grey shales" unit, located at the base of the westernmost "meseta" near Terrer. The "mesetas" exhibit successive sequences (3.5 to $12 \mathrm{~m}$ thick; Fig. 2) composed, from bottom to top, of (1) an irregular base overlying the previous sequence, (2) 2-5 $\mathrm{m}$ of reddish shales, partly cemented by carbonate, containing episodically greenish sandy marlstones (up to $0.8 \mathrm{~m}$ thick) with $\mathrm{mm}$-thick parallel lamination, interbedded mudcracks, and isolated $\mathrm{cm}$ - to dm- thick irregular gypsum nodules (0.5-1 m thick), and (3) nodular gypsum (0.2-1 m thick) on the top of the sequences. The lowermost sequence contains a distinct sandy marlstone bed, the thinnest nodular gypsum bed of the whole sequences, and is very rich in trace fossils. Reddish shales can be subdivided into small-scale cycles (cm-thick), composed of grading siltstone-to-argillite units, rich in organic matter, and overlain by common mudcracks. Each sequence represents the partial filling of the sub-basin by episodic inundites, scarce episodes of lacustrine deposition and the final widespread subaerial exposure of the sub-basin under arid conditions leading to evaporite deposition.

\section{SYSTEMATIC ICHNOLOGY}

A part of the illustrated specimens are housed in the Zaragoza University (MPZ 17122 to MPZ 17132) and some of them in the Institute of Geological Sciences of the Jagiellonian University in Krakow (acronym 159P).

\section{Celliforma GROUP}

This is an informal group that includes trace fossils bearing small single or clustered, elongated cells, commonly produced by hymenopteran insects. The erection of this group is useful because the determination of its ichnogenera in poorly preserved specimens is sometimes difficult. The group includes the ichnogenera Celliforma Brown, Uruguay Roselli, Palmiraichnus Roselli and Rosellichnus Genise and Bown, among others.

\section{Celliforma Brown, 1934}

\section{Diagnosis}

Vasiform, globular or subcylindrical cells commonly preserved as internal moulds; distal end rounded, and

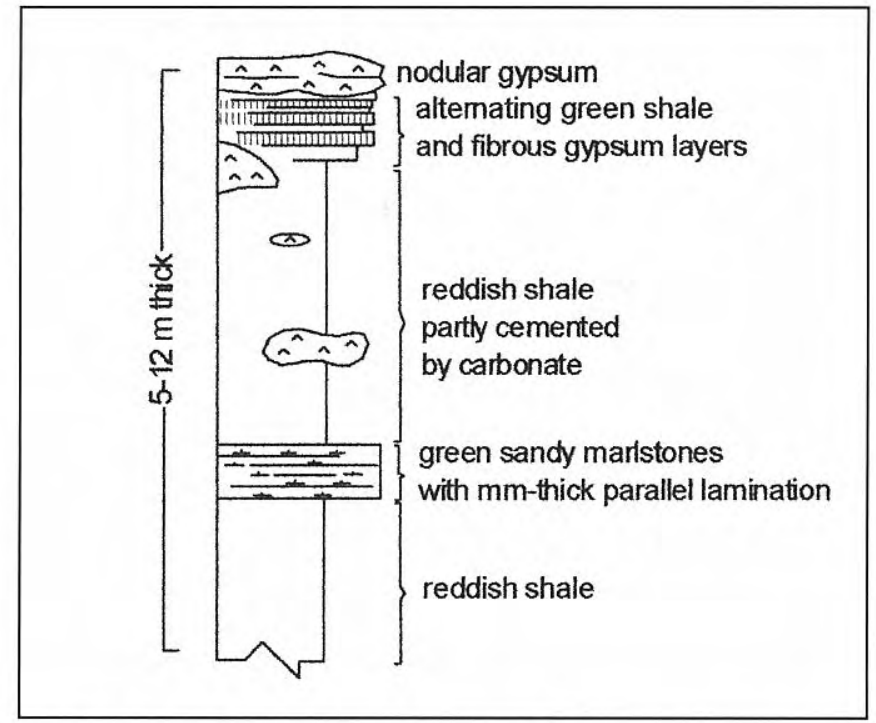

Figure 2. Stratigraphic section of the studied outcrops at Terrer.

proximal end either truncated irregularly or capped by a flat or conical closure, having spiral or concentric grooves on its inner surface; margins polished or smooth, so that internal moulds are easily separated from the rock matrix. The trace fossil lacks antechamber or wall (modified after Retallack, 1984, and using the criteria applied by Genise and Hazeldine, 1998).

\section{Remarks}

Traditionally, all the trace fossils defined by the first part of the above diagnosis have been recognized as Celliforma Brown. However, Genise and Hazeldine (1998) have separated the forms with antechamber and wall under the ichnogenus Palmiraichnus Roselli, 1987. In addition, the latter authors ascribed to Celliforma only solitary cells, while other authors include in Celliforma forms associated with galleries (Thackray, 1994; Elliot and Nations, 1998). The taxonomic affinity of Celliforma needs further discussion and revision (Retallack, 1984; Genise and Hazeldine, 1998), which is beyond the scope of this paper. Celliforma is generally regarded as bee cells (Brown, 1934; Elliot and Nations, 1998, with references).

\section{Celliforma isp. \\ Fig. 3A-I, M, P}

Material: About 70 specimens (159P1-11 and MPZ 17122$17124,17127,17131)$ and numerous observations in the field.

\section{Description}

Mostly oblique, rarely vertical (Figs. 3M, 3P), smooth vasiform cells, mostly up to 6-7 $\mathrm{mm}$ in diameter and 10-15 $\mathrm{mm}$ (exceptionally $18 \mathrm{~mm}$ ) long. The maximum width of the cells occurs between $1 / 3$ and $1 / 2$ of the length from the distal termination. The cells are slightly ellipsoidal in cross section. Some specimens display a distinct constriction in 
the proximal part (Fig. 3C). The distal end is rounded, whereas the proximal termination is irregularly truncated. One specimen (Fig. 3P) displays an inverted conical structure at the top, representing likely the remnant of the input-tunnel.

\section{Remarks}

It is not clear if all the identified forms belong to only one ichnospecies, because of the gradual transitions among different morphotypes, e.g. between those with constrictions and those more cylindrical. All of them are solitary and oriented in the same way. The described form is distinctly smaller than other solitary Celliforma. Moreover, C. spirifer Brown, 1934 displays a spiral closure (lid) of the cells. The absence of closures, however, can be related to the emergence of adults (Houston, 1987). C. germanica Brown, 1935 is characterized by a constriction at the middle part. Dimensions of the cylindrical, stout $C$. nuda Brown, 1935 are not known. C. ficoides Retallack, 1984 is typified by a long constriction in the proximal part, distinctly longer than in some of the described forms. In addition, it is larger and oriented subhorizontally in radial clusters. Other ichnospecies are clustered ( $C$. habari Thackray, 1994, C. rosellii Genise and Bown, 1994, C. dakotensis Elliot and Nations, 1998) or display a distinct wall ( $C$. arvernensis Ducreux, Billaud and Truc, 1988, C. pinturensis Genise and Bown, 1994, and C. gomezi Domínguez Alonso and Coca Abia, 1998). The latter two ichnospecies do not belong to Celliforma according to the above diagnosis, due to the presence of a distinct wall.

\section{Celliforma? isp. A} Fig. 3J-L

Material: 6 specimens (MPZ 17125-17126).

\section{Description}

Large, oblique, amphora-like cells resembling Celliforma, 12-17 $\mathrm{mm}$ in diameter and at least $35 \mathrm{~mm}$ long. Its cells are commonly intersected by subvertical shafts, which are about $5 \mathrm{~mm}$ in diameter. Celliforma ? isp. A is filled by poorly cemented brownish silt, which is easily removed during exploitation or by washing. For this reason, it is commonly preserved as cavities.

\section{Remarks}

Its not clear whether the described form displays a planar termination, which is an important diagnostic character for Celliforma (Edwards et al., 1997); therefore, we left it in an open nomenclature. The size of the found specimens corresponds to Celliforma arvernensis Ducreux, Billaud and Truc, 1988, from the Eocene of the Massif Central (France), but the latter form is walled, vertically oriented and more cylindrical in shape.

\section{Celliforma? isp. B Fig. 3N}

Material: 1 specimen (MPZ 17128).

\section{Description}

This specimen is composed of small cells arranged obliquely around the lower part of a vertical, slightly winding shaft. There are three, slightly oblique cells on one side and one poorly preserved cell on the other side of the shaft. Each cell is $8-9 \mathrm{~mm}$ long and up to $5 \mathrm{~mm}$ in diameter. The margin of the cells is very distinct in the distal part and badly preserved in the remaining part. The vertical shafts are at least $55 \mathrm{~mm}$ long and $4-5 \mathrm{~mm}$ in diameter.

\section{Remarks}

Cells attached to tunnels should be separated as a new ichnogenus (Genise, pers. commun., 1999) and, therefore, we described such forms in open nomenclature. Celliforma? isp. B resembles Celliforma ficoides Retallack, 1984 due to the oblique arrangement of the cells around the vertical shafts, but the cells of the latter form are characterized by the presence of a long constriction in the proximal part and stumpy cells. The geometry of Celliforma ? isp. B resembles the burrows made up by the halictine bee Lasioglossum (Dialictus) zephyrum (Eickwort, 1969), whose cells display a distinct "neck" resembling Cellifoma ficoides Retallack.

\section{Celliforma ? aff. habari Thackray, 1994 Fig. $3 \mathrm{O}$}

Material: 2 specimens (MPZ 17129-17130).

\section{Diagnosis of C. habari}

Subellipsoidal Celliforma cells, $6 \mathrm{~mm}$ long and 3.5 $\mathrm{mm}$ in diameter at the widest point; blunty truncated at the proximal end, dorsal surface curved and ventral surface nearly flat; cell lining $0.5 \mathrm{~mm}$ thick, crudely

Figure 3. Trace fossils from the sandy marlstone bed. Scale bar: $1 \mathrm{~cm}$ for all figures. A-G. Celliforma isp. extracted from the host rock. A: 159P1, B: 159P2, C: 159P3, D: 159P4, E: 159P5, F: 159P6, G: 159P7. H-I. Celliforma isp. Original position in the host rock. H: 159P10, I: MPZ 17123-17124. J. Celliforma ? isp. A. Horizontal parting surface. Filling washed out during preparation (field photograph). K-L. Celliforma ? isp. A. Horizontal parting surfaces (upper and lower side). Filling washed out during preparation. K: MPZ 17125, L: MPZ 17126. M. Celliforma isp. Original position in the host rock. MPZ 17127. N. Celliforma ? isp. B. Original position in the host rock. MPZ 17128 . O. Celliforma? aff. habari. Horizontal parting surface. MPZ 17129. P. Celliforma isp. Original position in the host rock. MPZ 17131. Q-R. Rosellichnus cf. arabicus. Horizontal parting surface. Top view. Q: 159P12, R: MPZ 17132, detail of Fig. 6F. S. Rosellichnus cf. arabicus. Horizontal parting surface. Basal view. MPZ 17133. 

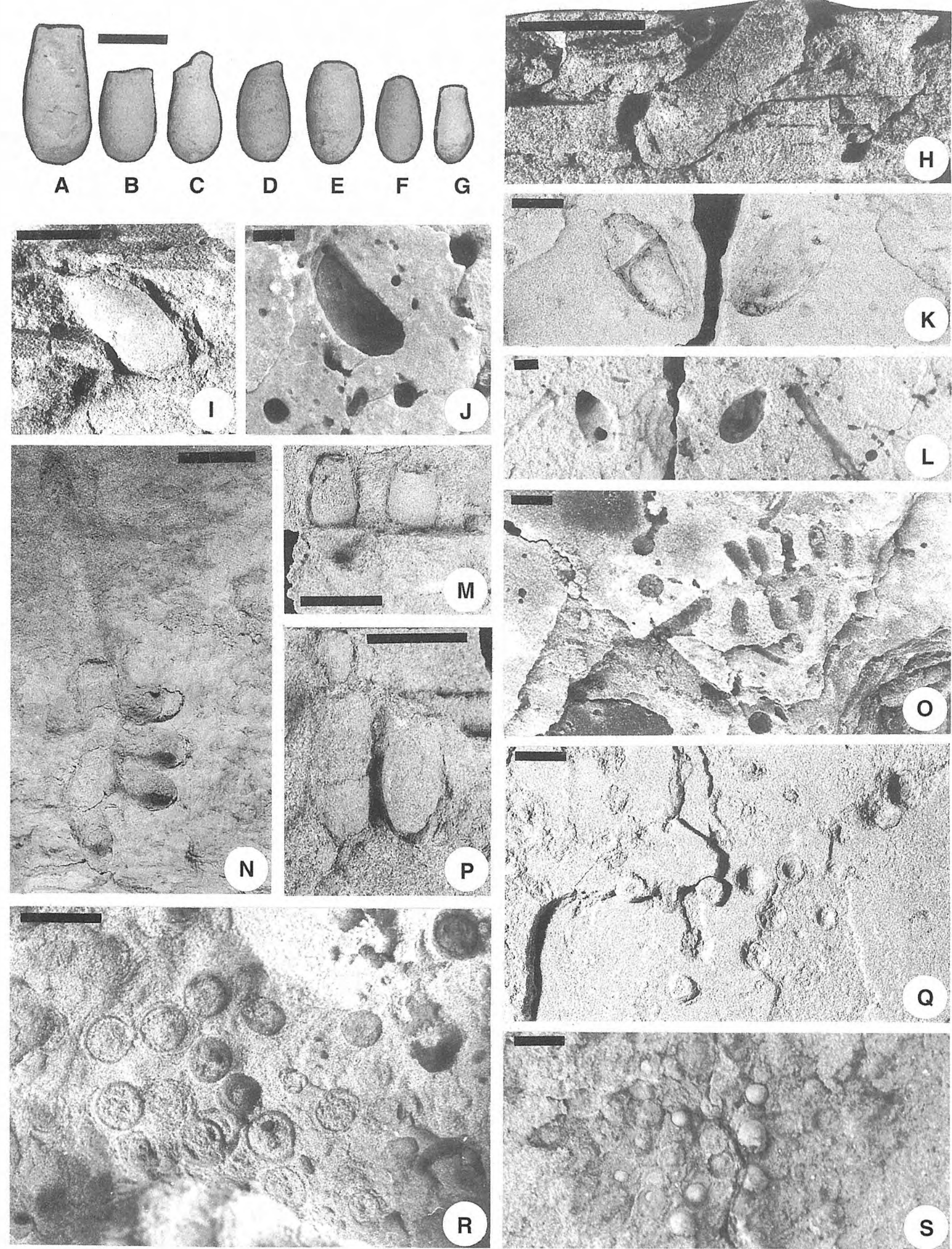
laminated; cells arranged in paired, parallel rows with typical $0.5-2 \mathrm{~mm}$ spacing between adjacent cells; $5 \mathrm{~mm}$ space between paired rows with blunty truncate ends of cells oriented inward; paired rows paralleling the paleosol surface or at acute angles $\left(30^{\circ}\right)$, clustered in groups around vertical axes (modified after Thackray, 1994).

\section{Description}

It is recognized by their semicircular, horizontal to subhorizontal grooves, partly associated with paired rows of shallow elliptical depressions. The grooves are sectioned endichnial central tunnels, and the depressions are sectioned cells. They were originally filled with soft brownish mudstones, subsequently washed out during preparation. The cells are about $10 \mathrm{~mm}$ long and $5 \mathrm{~mm}$ in diameter in the widest point, which is located between one third and half distance from their rounded termination. Only 10 cells are visible, which are 1-6 mm apart. They were probably more abundant, but are not preserved. The central tunnel $(5 \mathrm{~mm}$ in diameter) is almost straight in the place where the cells are located, and curved in the remaining part.

\section{Remarks}

According to Genise (pers. commun., 1999), cells attached to tunnels should be separated as a new ichnogenus, so that we described such forms in open nomenclature. $C$. habari from the Miocene of Kenya displays smaller and numerous cells bearing thin linings. They are more tear-shaped than the described form, and its central tunnel is not preserved. C. dakotensis Elliot and Nations, 1998, from the Upper Cretaceous of Arizona, is characterized by horizontal and vertical central tunnels, where the cells are bilaterally arranged around the horizontal tunnels and radially disposed around the vertical ones. In the described form, the cells are larger. It is not excluded that described form belongs to a new ichnospecies, but the material is insufficient for its erection. Celliforma habari should be excluded from the ichnotaxon Celliforma because its cells are clustered. Trace fossils similar to the described form are recently produced by the bee Halictus sexcinctus in middle Europe (Minkiewicz, 1934).

\section{Rosellichnus Genise and Bown, 1996}

\section{Diagnosis}

Groups of ovoid cells bearing distinct walls with smooth inner surfaces. The lower part of the cells are rounded, whereas their tops are flat and opened. The cells show parallel axes, and the upper part of their cluster is flat. The cells are arranged in a layer of several rows, whose bottoms and tops are at the same level forming a comb (after Genise and Bown, 1996, reduced).

\section{Remarks}

This ichnogenus may be produced by halictid bees forming underground nests (Genise and Bown, 1996). Halictid behaviour was described by Sakagami and Michener (1962) and Eickwort and Sakagami (1979). Rosellichnus differs from Uruguay in the upward convergence of the cells and the concave form of the upper part in Uruguay (after Genise and Bown, 1996).

\section{Rosellichnus cf. arabicus Genise and Bown, 1996 \\ Fig. 3Q-S}

Material: about 30 specimens (159P12, MPZ 1713217133).

\section{Diagnosis of $R$. arabicus}

Clusters of vertical cells arranged in 4-5 rows. It differs from $R$. patagonicus in having more rows of smaller cells. Cells are up to $8.5 \mathrm{~mm}$ in depth and show 6 $\mathrm{mm}$ as maximum diameter. Cell walls are thinner (about $1.0 \mathrm{~mm}$ ) than in $R$. patagonicus (Genise and Bown, 1996).

\section{Description}

Vertical, small, smooth, walled cells, $4-6 \mathrm{~mm}$ in diameter, grouped into clusters. The wall is $0.7-1.2 \mathrm{~mm}$ thick in the lower part of the cells. It is composed of three layers, visible using hand lens. The cells are circular or subcircular in cross-section, which are $0-3 \mathrm{~mm}$ apart. In one specimen, the upper part of a cluster of about 20 cells is visible in horizontal section. Some cells partially overlap each other, while others display slight lateral shifting. Preservation of the cells is very diverse, from relatively well preserved, with distinct contours, to completely indistinct. The cells within the clusters are poorly ordered, however single central rows can be distinguished. Their lower termination is rounded and located on slightly different levels.

\section{Remarks}

Rosellichnus arabicus, from the Miocene and Pleistocene of the United Arab Emirates (Genise and Bown, 1996), to which the described material is compared, occurs in combs with terminations of cells at the same level. Despite the differences, the similarities are strong enough to suppose that the described form was produced by halictid? bees (the behaviour of solitary bees has been described by Batra, 1984). The differences in preservation of individual cells and the overlapping features in the described material suggest that the bees reoccupied the cells several times.

Figure 4. Trace fossils from the sandy marlstone bed at Terrer. Scale bar: $1 \mathrm{~cm}$ for all figures. A-B. Spongeliomorpha isp. Oblique parting surface. A: MPZ 17134, B: MPZ 17135. C-E. Labyrintichnus terrerensis. Base of the bed. Holotype in E. C-D: field photographs, E: MPZ 17136. 

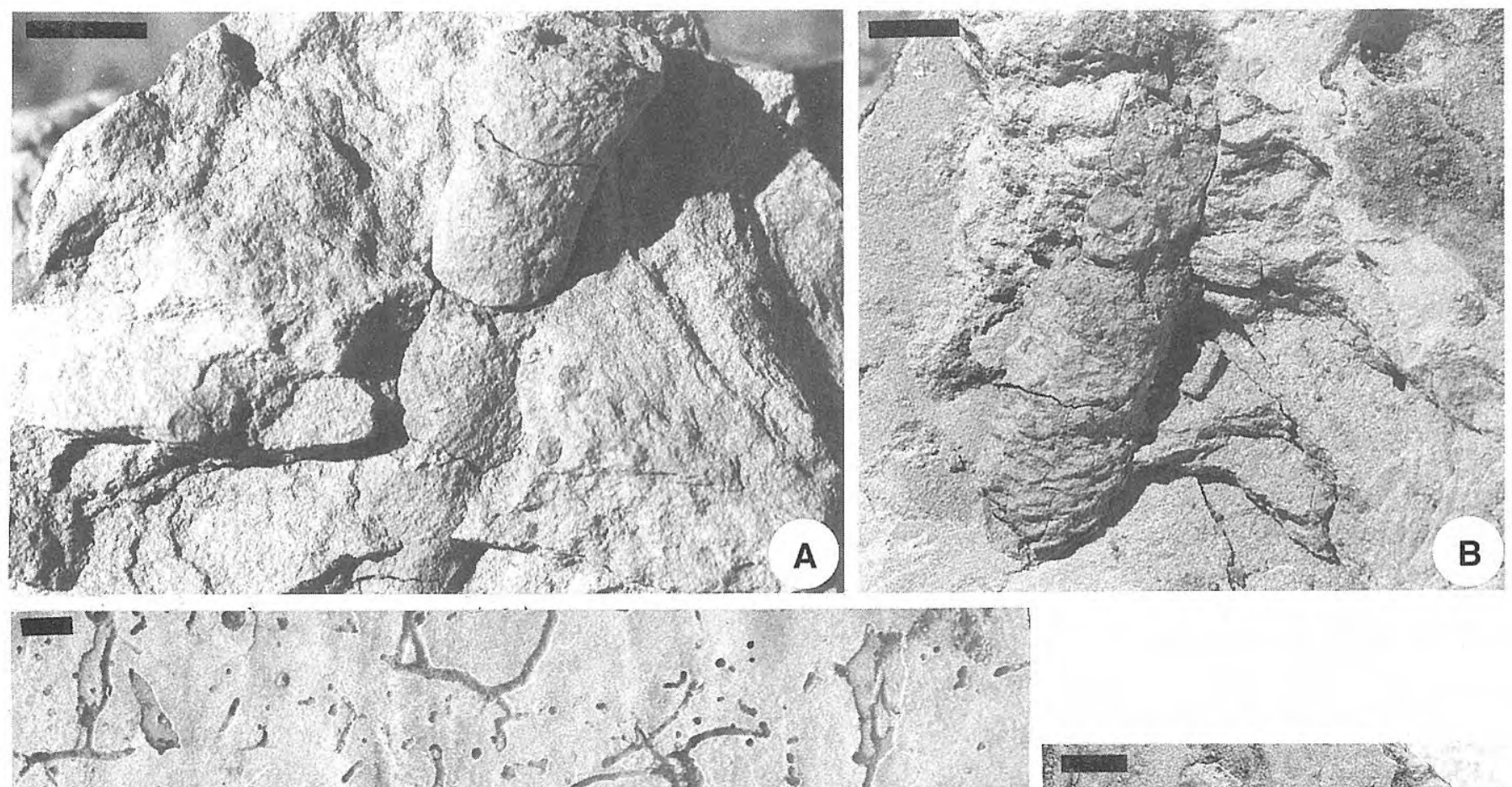

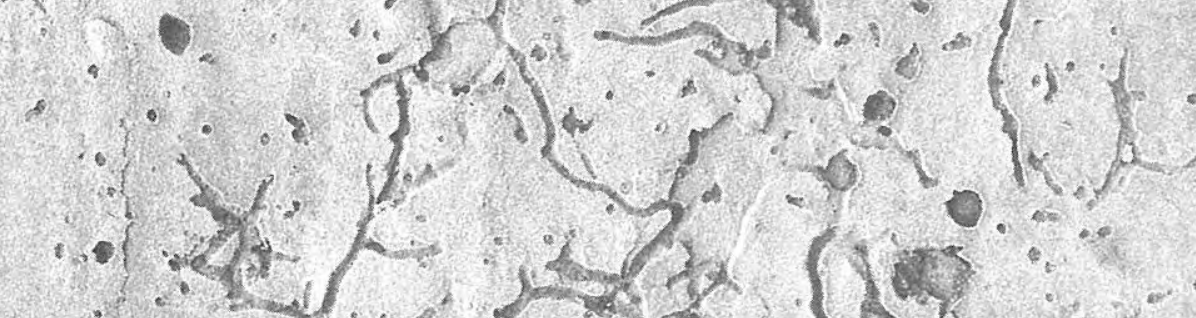

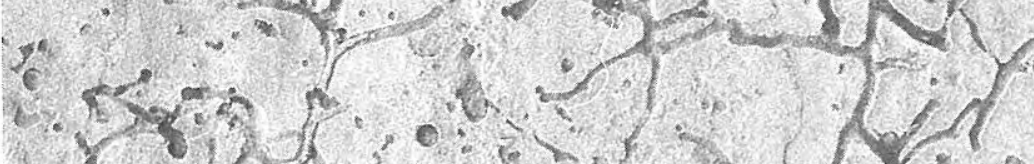

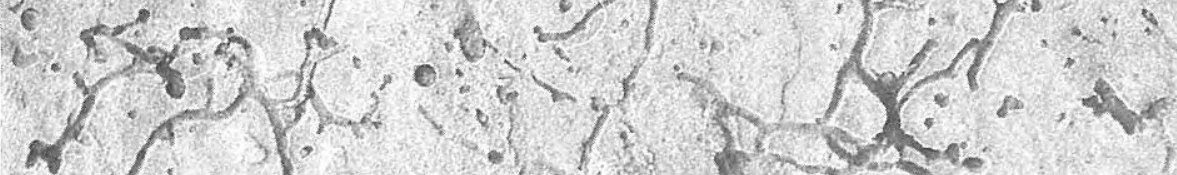

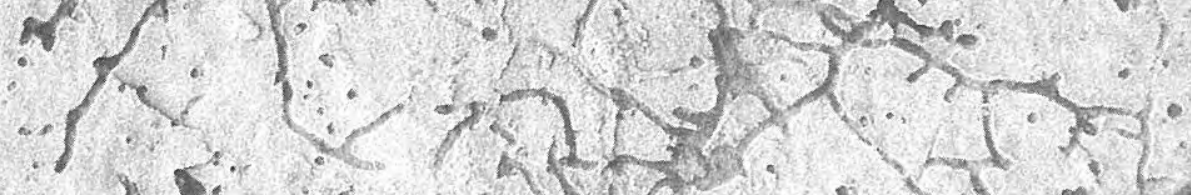

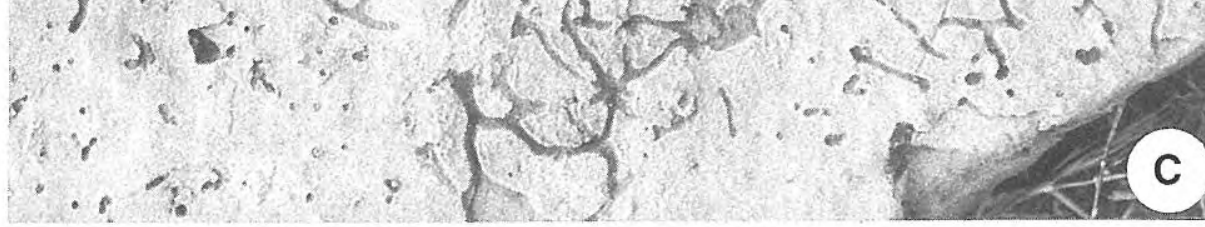

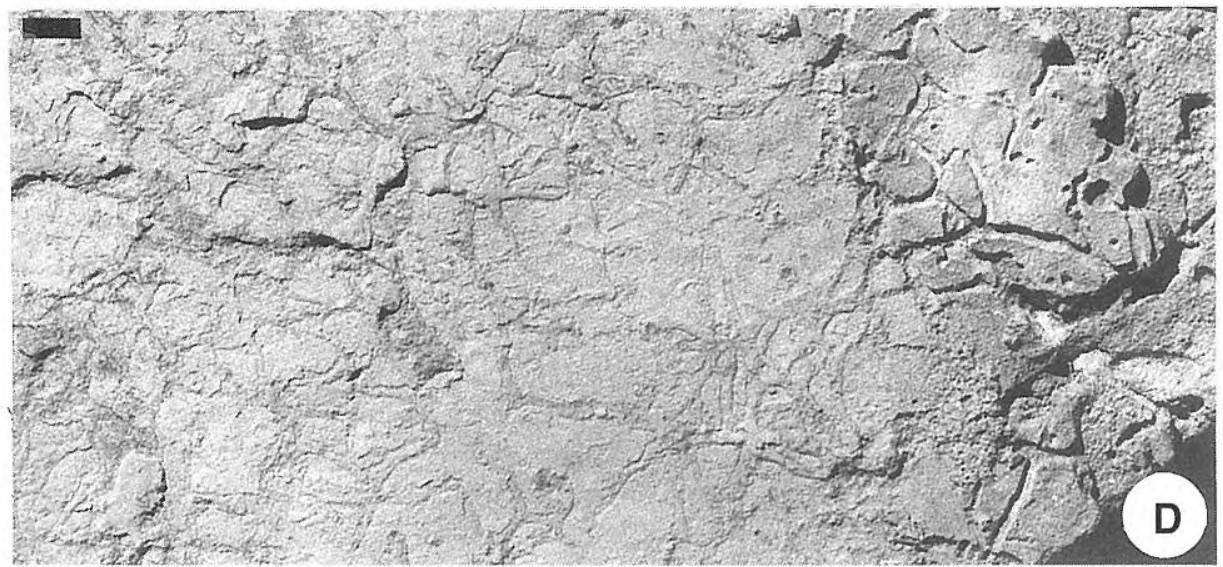

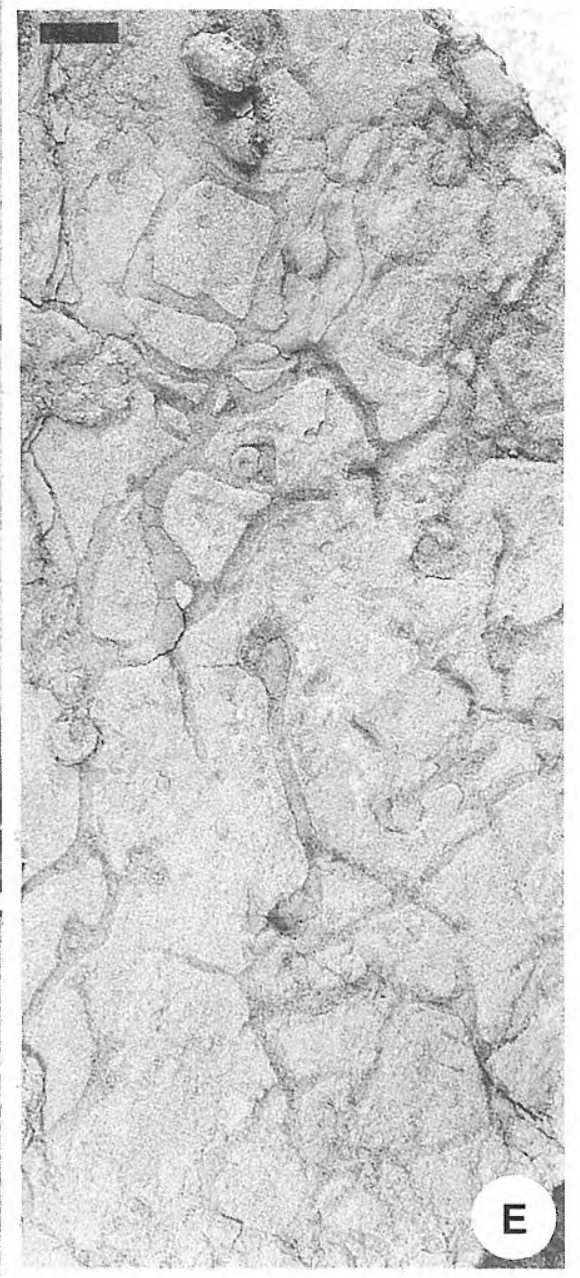




\section{OTHER TRACE FOSSILS}

\author{
Spongeliomorpha Saporta, 1887
}

\section{Diagnosis}

Sparsely developed burrow systems, with vertical to horizontal components characterized by sets of longitudinal to oblique, fine, elongate striae on the exterior of the burrow casts (Fürsich et al., 1981; Frey et al., 1984).

\section{Remarks}

The marine Spongeliomorpha was produced by crustaceans in firm substrates. Its origin and nomenclatural problems have been discussed by Fürsich (1973), Bromley and Frey (1974), Frey et al. (1984) and others. Non-marine Spongeliomorpha has been reported by Bromley and Asgaard (1979) and Metz (1990). Similarly to the marine forms, the non-marine Spongeliomorpha indicates also firm-ground substrates (Ekdale et al., 1984).

\section{Spongeliomorpha isp.} Fig. 4A-B

Material: 2 specimens (MPZ 17134-17135).

\section{Description}

Oblique to straight, unlined cylindrical, isolated trace fossils, covered with oblique wrinkles, which are about 5 $\mathrm{mm}$ long and less than $1 \mathrm{~mm}$ wide. The wrinkles occur in bundles, forming a chevron pattern. They are interpreted as casts of scratch marks. The cylinders are 11-12 $\mathrm{mm}$ in diameter.

\section{Remarks}

The Late Triassic Spongeliomorpha milfordensis Metz, 1993, from lake-margin deposits, displays a similar pattern of scratch marks, but it is predominantly horizontal, branched, and less than $5 \mathrm{~mm}$ in diameter. Mole crickets (Orthoptera: Gryllotalpidae) produce similar oblique scratches in their holes, but their tunnels are smaller (Metz, 1990). The Upper Triassic Spongeliomorpha carlsbergi Bromley and Asgaard, 1979 (Ekdale et al., 1984) shows comparable size, but it is dominantly horizontal and displays perpendicular to sub-perpendicular striae. The scratches of the striated oblique burrows (Bromley and Asgaard, 1979) are similar, but they are denser, cross-cutting themselves and longer. The forms described by Bromley and Asgaard (1979) belong to the "terrestrial suite" associated with lacustrine sediments.
Labyrintichnus $\mathrm{n}$. igen.

Derivation of name: from labyrinthine burrow system.

Type ichnospecies: Labyrintichnus terrerensis $\mathrm{n}$. isp.

\section{Diagnosis}

Cylindrical trace fossils composed of irregular nets, in which some cylinders can be disconnected on different levels. Vertical or oblique shafts can be present. Filling is passive.

\section{Discussion}

Labyrintichnus displays some similarities to Megagrapton Książkiewicz, 1968, Multina OrXowski, 1968, Pseudopaleodictyon Pfeiffer, 1968, Olenichnus Fedonkin, 1985, and Vagorichnus Buatois, Mángano, Wu and Zhang, 1995. Megagrapton (see Uchman, 1998), similarly to Labyrintichnus (see discussion below), is referred to open burrow systems, but its net is more regular and occurs on the same plane. Generally, the tunnels do not disappear on different levels. Multina (see OrXowski and Żylińska, 1996), and its junior synonyms Olenichnus and Vagorichnus, display active filling; probably, the same can be said of Pseudopaleodictyon Pfeiffer. The passive filling indicates an open burrow system. Its separation from similar but actively filled burrows is very significative, as discussed in the case of Palaeophycus and Planolites (Pemberton and Frey, 1982).

\section{Labyrintichnus terrerensis $\mathrm{n}$. isp. Fig. 4C-E, Fig. 5A-C}

Derivation of name: from the village of Terrer (Spain), where the trace fossil was found.

Holotype: MPZ 17136 (Fig. 5D).

Type locality: Terrer (Zaragoza).

Dimensions of the holotype: a plate of $10 \times 8 \mathrm{~cm}$ bearing an irregular net with burrows less than $1 \mathrm{~cm}$ wide.

Stratigraphic setting: $1.5 \mathrm{~m}$ above the bottom of the westernmost Tertiary meseta near Terrer, along the old road N-II.

Material: 8 specimens (MPZ 17136, 159P13).

Diagnosis: the same as for the ichnogenus.

Figure 5. Trace fossils from the sandy marlstone bed (A-C) and from the lacustrine mudstones (D-G). Scale bar: $1 \mathrm{~cm}$ for all figures. A-B. Taenidium barreti, morphotype A. Parting surface close to the base of the bed. B is a detail of A. Labyrintichnus terrerensis in background. MPZ 17137. C. Taenidium barreti, morphotype B. Parting surface close to the base of the bed. Labyrintichnus terrerensis in background. MPZ 17138. D-G. Beaconites filiformis. Polished surfaces. D: holotype, MPZ 17139. D, E, G: vertical cross-section. F: horizontal section. M in E indicates crosssections of mudcracks. E: MPZ 17140, F: MPZ 17139, G: MPZ 17141. 

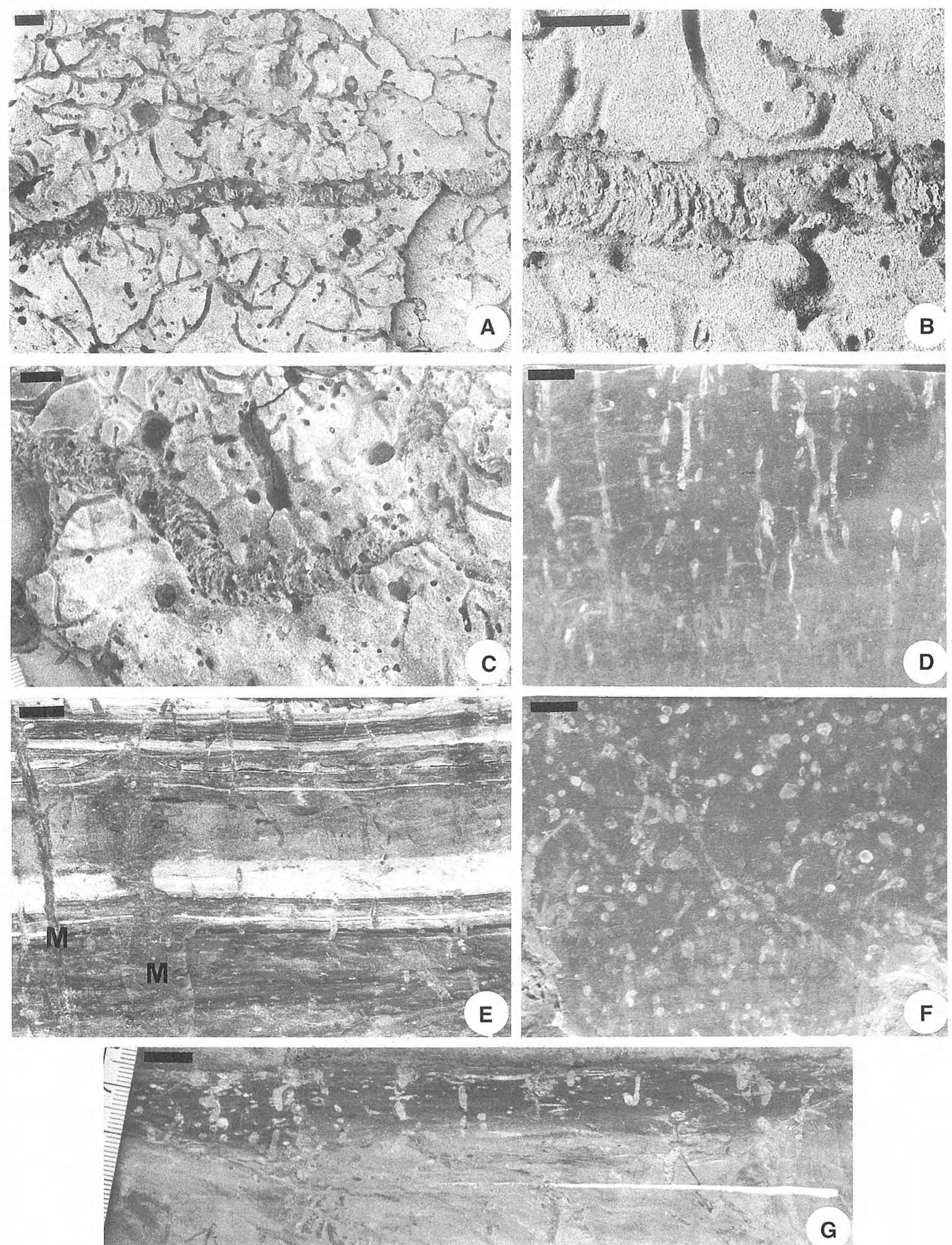


\section{Description}

Horizontal, irregular net composed of branched, slightly winding cylinders, which are $1-3 \mathrm{~mm}$ in diameter (the majority about $2 \mathrm{~mm}$ ). Locally, they are thinly lined. The cylinders can overlap themselves. Some of them belong to different systems produced at different time. In a few specimens (Fig. 4D-E), the burrow system is collapsed. Tunnels display a distinct lining; in some cases, the tunnels can be disconnected on slightly different levels.

Locally, a master-like tunnel with lateral, somewhat short branches is visible; however, the tendency to form an irregular net still occurs. The net is associated with vertical to sub-vertical shafts of similar diameter. Some tunnels change slightly their width; however, this can be an effect of the intersection of the bed surface with the tunnels that are slightly winding in the vertical plane. Locally, the tunnels are slightly enlarged at the point of branching. The filling material, composed of red mudstones, was easily removed by washing, but in some nets it is still preserved within the tunnels.

\section{Discussion}

The lining, enlargements in the point of branching, and filling from overlying beds indicate that this trace fossil was an open burrow system composed of a horizontal labyrinth with vertical and oblique shafts, which could have been produced by beetles or their larvae. Similar burrow systems are produced by ground beetles (Carabidae) and variegated mud-lowing beetles (Heteroceridae). The latter ones produce, however, shallow burrows below the ground surface (Ratcliffe and Fagerstrom, 1980). The tunnels of L. terrerensis were produced mostly at the boundary of sandy marlstones with underlying mudstones. Such a place can help to keep the proper moisture and/or temperature for trace-makers or their juveniles.

\section{Taenidium Heer, 1877}

\section{Diagnosis}

Variably oriented, straight, winding, curved or sinuous, essentially cylindrical, meniscate backfilled trace fossils. Secondary successive branching may occur, but true branching is absent (after Keighley and Pickerill, 1994).

\section{Remarks}

Ichnotaxonomic problems of Taenidium, related meniscate backfilled burrows and their formation were discussed in detail by D'Alessandro and Bromley (1987), Keighley and Pickerill (1994) and Uchman (1995). Taenidium occurs from the Lower Cambrian (Crimes et al., 1992) to the Quaternary? (Wetzel, 1983; synonymized by D'Alessandro and Bromley, 1987).

\section{Taenidium barreti (Bradshaw, 1981)}

Fig. 5A-C

Material: 2 specimens (MPZ 17137-17138).

\section{Diagnosis}

Straight to variably meandering, unbranched, unwalled, meniscate backfilled burrow. Menisci are commonly hemispherical or deeply arcuate, tightly packed or stacked, forming non-systematic backfill or thin meniscate burrows (after Keighley and Pickerill, 1994).

\section{Description}

Morphotype A (Fig. 5A-B). Horizontal, slightly winding, cylindrical trace fossils $(9-10 \mathrm{~mm}$ wide) with meniscate filling. Menisci are relatively shallow grouped into 10 units per $\mathrm{cm}$. Some tunnels of L. terrerensis, located along the margin, mimic a wall; however, the latter structure is not present, as can be clearly seen in the remaining parts of the trace fossil.

Morphotype B (Fig. 5C). Horizontal, strongly winding cylindrical, unwalled trace fossils with meniscate filling. The cylinders are $10-12 \mathrm{~mm}$ wide and contain about 5 menisci per $\mathrm{cm}$. Some groups of menisci are wider, and hence the burrow margin is slightly undulate.

\section{Remarks}

T. barretti occurs in Lower Ordovician to Pleistocene non-marine environments (Keighley and Pickerill, 1994). Squires and Advocate (1984) described this ichnospecies (as Muensteria? isp.) from a Miocene section in California related to mixed environments in which a braided river entered a lake. These authors interpreted the meniscate burrows as traces of infaunal deposit-feeders, probably aquatic oligochaetes.

\section{Beaconites Vialov, 1962}

\section{Diagnosis}

Small, cylindrical, unbranched, walled, meniscate burrows. They are straight to sinuous, horizontal or moderarely inclined to vertical. They display weakly to strongly arcuate meniscate packets or segments enclosed by distinct, smooth burrow linings (Keighley and Pickerill, 1994) without external ornamentation.

\section{Beaconites filiformis n. isp. Fig. 5D-G}

Derivation of name: after filus (Latin) - thread.

Holotype: MPZ 17139 (Fig. 6D).

Figure 6. Trace fossils from the sandy marlstone bed. Scale bar: $1 \mathrm{~cm}$ for all figures. A-E Polykladichnus aragonensis. Vertical parting surfaces. The holotype $(\mathrm{P})$ in A. The vertical branched shafts in A-C (arrows). A: MPZ 17137, B: MPZ 17142, C: MPZ 17142, D-E: field photographs. F. Rosellichnus cf. arabicus (in the lower part, detail in Fig. 3R), Labyrintichnus terrerensis, and ?washed out Taenidium barreti (T). Base of the bed. MPZ 17132. 

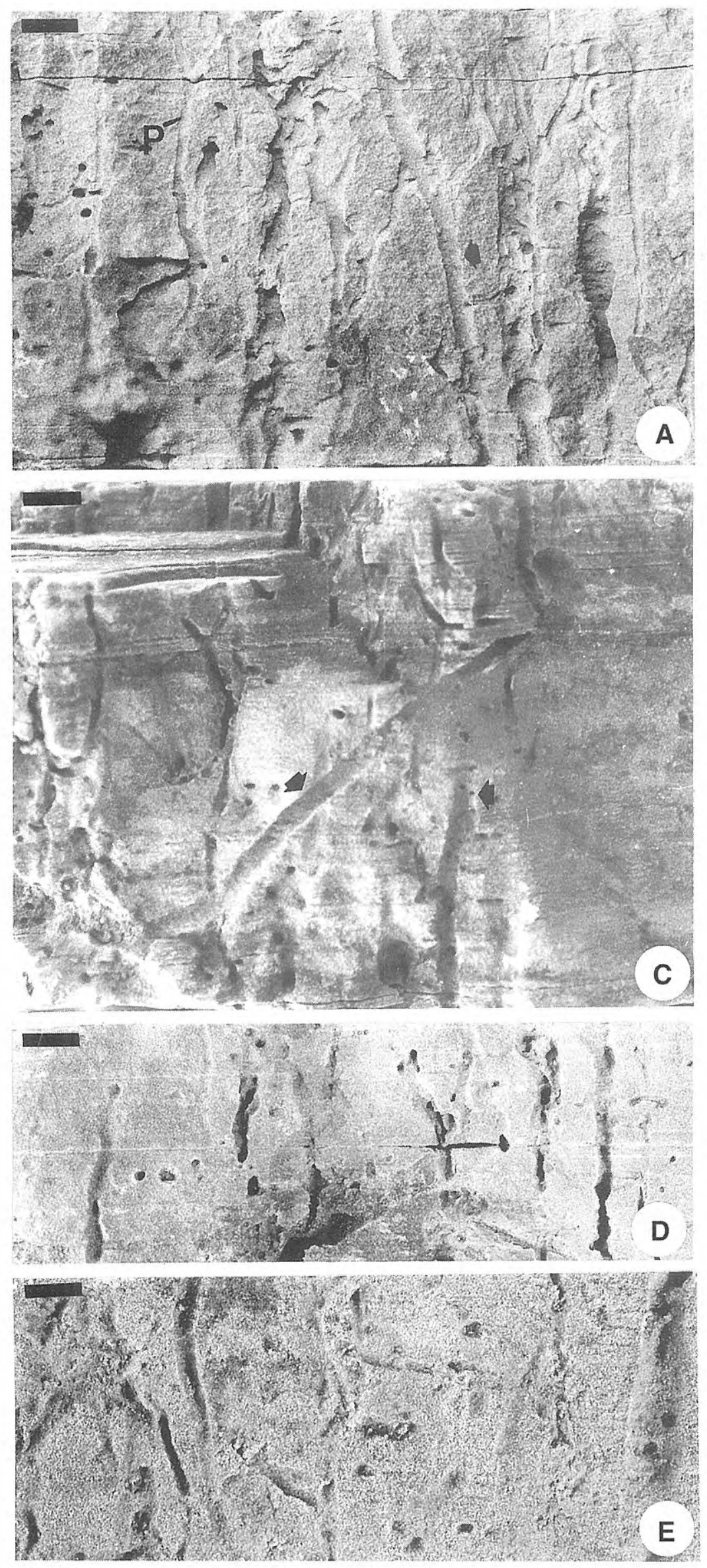
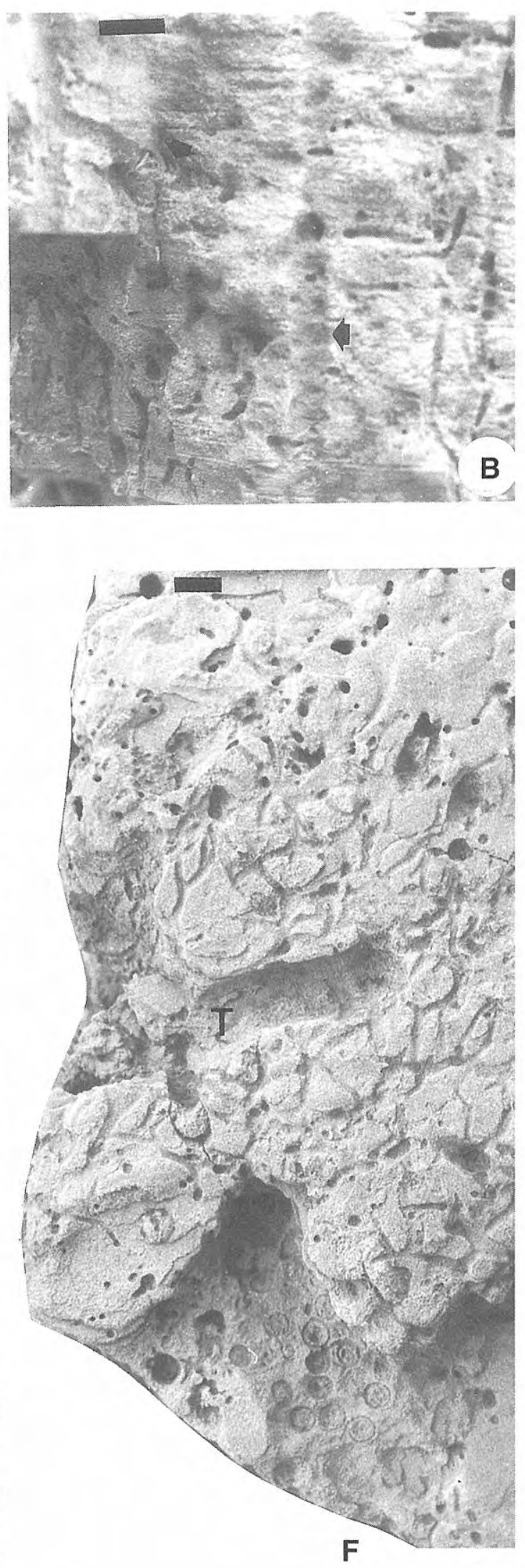
Type locality: Terrer (Zaragoza).

Dimensions of the holotype: a sample of about $20 \times 10 \mathrm{~cm}$, bearing a swarm of burrows at least $8 \mathrm{~cm}$ long.

Stratigraphic setting: $1 \mathrm{~m}$ above the bottom of the westernmost Tertiary meseta near Terrer, along the old road N-II.

Material: more than 30 specimens (MPZ 17139-17141, 159P14-16).

\section{Diagnosis}

Predominantly vertically oriented, slightly winding, thinly lined Beaconites, whose diameter is less than 5 $\mathrm{mm}$.

\section{Description}

Slightly winding, mostly vertical, but locally oblique, thinly lined, cylindrical trace fossils in which filling is locally meniscate. Their filling differs in colour and commonly in grain-size from the host rock. The trace fossils are $0.8-3.5 \mathrm{~mm}$ in diameter and at least $80 \mathrm{~mm}$ long. In some layers, they are very dense, up to 10 burrows per square $\mathrm{cm}$ of horizontal section. The trace fossil does not display true branches sensu D'Alessandro and Bromley (1987), but false and secondary successive branches.

\section{Remarks}

B. filiformis can be ascribed to Beaconites because of the meniscate filling and distinct lining. This ichnospecies differs from other Beaconites ichnospecies (see Keighley and Pickerill, 1994 for review) by its vertical orientation, small size and thin lining. $B$. filiformis was produced probably by larvae of Chironomidae. The same interpretation was given to a little larger and more variable oriented "type 3, tanglepatterned small burrows" from the Miocene hypersaline lake sediments of Spain (Rodríguez-Aranda, 1992). Larvae of Chironomidae are mostly organic detritus feeders and can occur in very dense populations (Oliver, 1971). They construct different types of lined tubes (McCall and Tevesz, 1982). According to Chamberlain (1975), their tubes are 0.5 to $3 \mathrm{~mm}$ across and up to 15 cm deep.

\section{Polykladichnus Fürsich, 1981}

\section{Diagnosis}

Lined or unlined, vertical tubes with Y- or U-shaped bifurcations with slight enlargements at points of bifurcation, usually connected to the bedding surface (after Schlirf et al., in press).

\section{Remarks}

Polykladichnus is typified by $P$. irregularis Fürsich, 1981 from Jurassic, marginal marine deposits of Portugal. It is described as a small burrow with a lined tube, 2-5 $\mathrm{mm}$ in diameter, and $\mathrm{Y}$-shaped bifurcations. The herein described $P$. aragonensis is unlined and displays U- shaped bifurcations. However, the upward directed, Y- or $\mathrm{U}$-shaped bifurcations are regarded as the most significant diagnostic features in this ichnogenus. For this reason, the former diagnosis of Fürsich (1981) is emended (Schlirf et al., in press). Arborichnus Ekdale and Lewis, 1991 from the Quaternary fan delta deposits of New Zealand, can be included in Polykladichnus according to the proposed diagnosis.

\section{Polykladichnus aragonensis n. isp.} Fig. 6A-E

Derivation of name: from the Aragón Region (Spain).

Holotype: MPZ 17137 (Fig. 6A, specimen indicated by P).

Type locality: Terrer (Zaragoza).

Dimensions of the holotype: a slab up to $8 \mathrm{~cm}$ thick, bearing a swarm of burrows up to $9 \mathrm{~cm}$ long.

Stratigraphic setting: $1.5 \mathrm{~m}$ above the bottom of the westernmost Tertiary meseta near Terrer, along the old road N-II.

Material: about 30 specimens (MPZ 17137-17142).

\section{Diagnosis}

Unlined Polykladichnus bearing slightly winding tubes, which display Y-bifurcations or U-shaped elements.

\section{Description}

Vertical to inclined cylindrical shafts, straight or slightly winding, single (?) or bearing Y-shaped branchings or curved U-shaped bifurcations. They are 1-2 $\mathrm{mm}$ in diameter and at least $90 \mathrm{~mm}$ long. Some tubes display several orders of bifurcations.

\section{Remarks}

Arenicolites isp. described by Bromley and Asgaard (1979) in the Upper Triassic lacustrine deposits of the Fleming Fjord Formation (East Greenland) is very similar. It was interpreted as a burrow of tubificid oligochaetes but, according to Chamberlain (1975), oligochaetes construct branched, radiating downwards tubes, similar to Chondrites. McCall and Tevesz (1982) illustrated oligochaete burrows from the Lake Erie, which form dense, three-dimensional, labyrinthine burrows. This type of branching is not observed in the described material. Burrows with upward bifurcations are produced by staphylinid beetles of the genus Bledius, described by Larsen (1936) in the Recent sandy beaches and dunes of Denmark. Walshe (1951) and Chamberlain (1975) mentioned U-shaped burrows of chironomids, but Chironomus plumosus produces shallow U-tubes without shafts (McCall and Tevesz, 1982). The mayfly Hexagonia limbata produces burrows composed of Ushaped elements with occasional blind shafts 


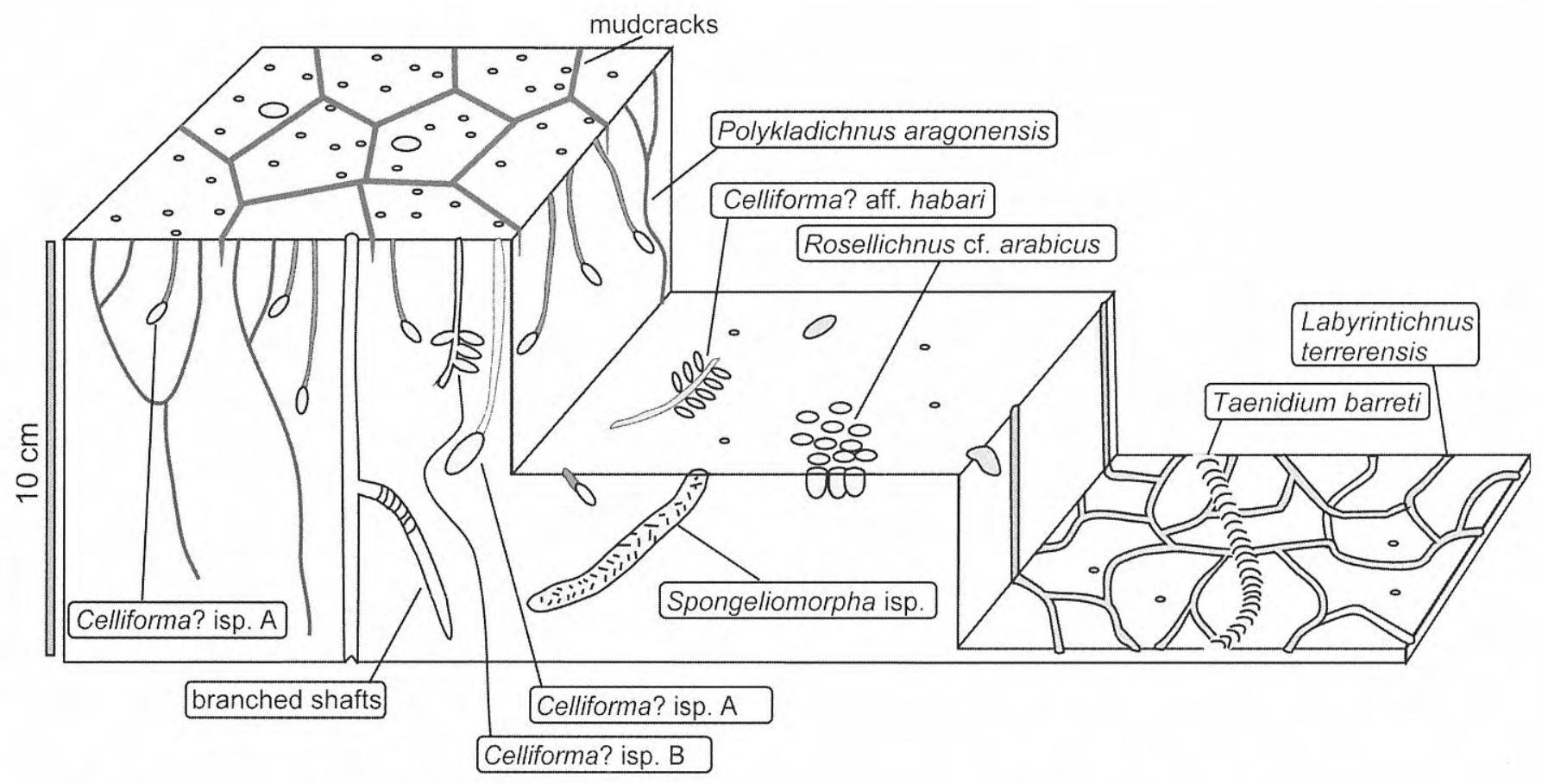

Figure 7. Distribution of trace fossils in the sandy marlstone bed. Trace fossils not at scale.

(Charbonneau and Hare, 1998). These similarities allow us to suppose that $P$. aragonensis was produced by insects or their larvae.

\section{Branched shafts \\ Fig. 6A-C}

Material: about 10 specimens (MPZ 17142).

\section{Description}

Vertical to oblique, straight to slightly curved, unwalled cylindrical tunnels (3-4 mm in diameter), rarely branched. The branches, going obliquely downwards, are locally indistinctly meniscated. Rare, second-order branches occur.

\section{Remarks}

Tiger-beetles (Cicindelidae), which are common on moist areas of stream and lake shores, construct similar shelter burrows (Chamberlain, 1975). The modal diameter of burrows in Recent fluvial plains of Nebraska ranges between 3 and $4 \mathrm{~mm}$ (Stanley and Fagerstrom, 1974). Chamberlain (1975) mentioned that some cicindelid beetles pack the sediment behind during burrowing. This can suggest occurrence of a meniscate filling, present locally in the described form.

\section{DISTRIBUTION OF TRACE FOSSILS AND COMMUNITY REPLACEMENTS}

Almost all the trace fossils described above occur in one sandy marlstone bed of the Terrer section. The red lacustrine mudstones contain mainly Beaconites filiformis. Labyrintichnus terrerensis occurs at the basal part of the sandy marlstone bed (Fig. 7). It is cross cut by
Taenidium barreti, whereas vice versa examples are rare. Celliforma isp., Celliforma ? ispp., and Rosellichnus cf. arabicus occur in the middle and upper parts of the marlstone bed. They are cross cut by branched shafts. Finally, all the previous trace fossils of the marlstone bed are cross cut by Polykladichnus aragonensis. The cross cutting relationships reflect a benthic community replacement in the colonisation of the substrate, which is controlled by external factors, such as the moist ground features of the substrate.

The density of the trace fossils is diverse. Celliforma isp., Labyrintichnus terrerensis, Beaconites filiformis, Polykladichnus aragonensis and the branched shafts are very common. The other forms are less common, and Rosellichnus cf. arabicus is rare.

The trace fossils produced by the activities of insects, other arthropods and oligochaete worms described above can be grouped into three broad categories or ichnofacies, which represent three phases of community replacement:

1. Celliforma isp., Celliforma ? ispp. and Rosellichnus cf. arabicus (produced by Hymenoptera) represent the Termitichnus ichnofacies (Buatois and Mángano, 1995), which indicates a terrestrial environment. Hymenoptera insects installed their nests in non-inundated, preferentially dry, commonly well-insolated grounds. The open burrow system of Labyrintichnus terrerensis was likely produced also in relatively dry grounds.

2 . The meniscate Taenidum barreti and the branched shafts were produced rather in moist grounds. They are typical representatives of the Scoyenia ichnofacies (Buatois and Mángano, 1995, 1998). Spongeliomorpha isp. was produced in a cohesive, slightly firm ground. According to the latter authors, the Scoyenia ichnofacies is indicative of a transitional zone between terrestrial and subaqueous settings. According to Bromley and Asgaard (1979), the above trace fossils belong to the "terrestrial 
suite". However, it is not clear which kind of substrate was colonized by Polykladichnus aragonensis. Other similar traces, such as Arenicolites isp., were ascribed to the "aquatic suite" by Bromley and Asgaard (1979). However, $P$. aragonensis can be produced by beetles in terrestrial environments (see discussion of the ichnotaxon). According to the scheme of non-marine ichnofacies of Buatois and Mángano (1995, 1998), the vertical trace fossils belong to the Scoyenia ichnofacies.

3. Beaconites filiformis is also a vertical trace fossil, but was produced in subaqueous environments, probably by chironomids. In the lower part of the described sedimentary sequences, this trace fossil occurs in beds affected by desiccation cracks, which are indicative of periodically drying out, shallow lacustrine deposits. However, in the upper part of the sequences, B. filiformis occurs in full subaqueous deposits, where the Mermia ichnofacies should occur. The latter ichnofacies contains different, small, horizontal, mostly grazing traces (Buatois and Mángano, 1995, 1998). The absence of this kind of traces can be caused by hypersaline conditions (indicated by precipitation of evaporitic remains), which eliminated most of typical animals in fresh-water lacustrine environments. Chironomid larvae can live in highly saline lakes (Rodríguez-Aranda and Calvo, 1998).

The cross-cutting relationships of trace fossils in the basal sandy marlstone indicate that the Termitichnus ichnofacies is replaced by the Scoyenia ichnofacies; the overlying beds contain only the subaqueous Beaconites filiformis. All the succession indicates a transition from dry-ground terrestrial to moist-ground environments, finally replaced by subaqueous conditions. The red lacustrine mudstones fill the open-burrow systems of the Termitichnus and Scoyenia ichnofacies. The Miocene lacustrine cycles of the Calatayud-Teruel basin seemingly display at least three community replacements in trace fossil distribution, indicating similar palaeoenvironmental changes. This enhances ichnological methods in investigations of lacustrine sedimentation processes.

\section{CONCLUSIONS}

A new ichnogenus (Labyrintichnus) and three new ichnospecies (Labyrintichnus terrerensis, Polykladichnus aragonensis and Beaconites filiformis) are erected in the Miocene lacustrine deposits of the Calatayud-Teruel basin (NE Spain). The whole ichnoassemblage includes, in the locality of Terrer, representatives of the Termitichnus ichnofacies (Celliforma isp., Celliforma? ispp. A and B, Celliforma? aff. habari, Rosellichnus cf. arabicus, Labyrintichnus terrerensis), the Scoyenia ichnofacies (Taenidium barreti, Spongeliomorpha isp., vertical shafts and probably Polykladichnus aragonensis), and an equivalent of the Mermia ichnofacies (Beaconites filiformis). The trace fossils were produced by burrowing insects, other arthropods and oligochaetes.

The vertical succesion of the Termitichnus ichnofacies, Scoyenia ichnofacies and the equivalent of the Mermia ichnofacies indicates a gradual transition from dry-ground terrestrial to moist ground environments, finally replaced by subaqueous conditions. These community replacements are related to episodic floodings of the lacustrine Calatayud sub-basin and subsequent evaporation leading to the development of dry grounds colonized by a wide diversity of soft-bodied animals.

The occurrence of a monospecific ichnoassemblage, composed of vertical Beaconites filiformis (produced probably by chironomid larvae) in the lacustrine sediments, is probably caused by hypersaline contitions (evinced by precipitation of evaporites), which eliminated typical fresh-water trace-makers responsible for the production of the horizontal traces indicative of the Mermia ichnofacies.

\section{ACKNOWLEDGMENTS}

We are grateful to Jorge F. Genise, Jordi M. de Gibert and Eduardo Mayoral for their constructive comments on an early version of the manuscript. Traveling of A.U. to Spain was sponsored by the Alexander von Humbold Foundation. Part of laboratory researches was supported by the Jagiellonian University.

\section{REFERENCES}

Batra, S. W. T. 1984. Solitary bees. Scientific American, 250 (February), 86-93.

Bradshaw, M. 1981. Paleoenvironmental interpretations and systematics of Devonian trace fossils from the Taylor Group (Lower Beacon Supergroup), Antarctica. New Zealand Journal of Geology and Geophysics, 24, 61-652.

Bromley, R. G. and Asgaard, U. 1979. Triassic fresh water ichnocoenosis from Carlsberg Fjord, East Greenland. Palaeogeography, Palaeoclimatology, Palaeoecology, 28, 39-80.

Bromley, R. G. and Frey, R. W. 1974. Redescription of the trace fossil Gyrolithes and taxonomic evaluation of Thalassinoides, Ophiomorpha and Spongeliomorpha. Bulletin of the Geological Society of Denmark, 23, 311335.

Brown, R.W. 1934. Celliforma spirifer, the fossil larval chambers of mining bees. Journal of the Washington Academy of Sciences, 24, 532-539.

Brown, R.W. 1935. Further notes on fossil larval chambers of mining bees. Journal of the Washington Academy of Sciences, 25, 526-528.

Buatois, L. A. and Mángano, M. G. 1995. The paleoenvironmental and paleoecological significance of the lacustrine Mermia ichnofacies: an archetypical subaqueous nonmarine trace fossil assemblage. Ichnos, 4, 151-161.

Buatois, L. A. and Mángano, M.G. 1998. Trace fossil analysis of lacustrine facies and basins. Palaeogeography, Palaeoclimatology, Palaeoecology, 140, 367-382.

Buatois, L.A., Mángano, M.G., Wu Xiantao and Zhang Guocheng. 1995. Vagorichnus, a new ichnogenus for 
feeding burrow systems and its occurrence as discrete and compound ichnotaxa in Jurassic lacustrine turbidites of Central China. Ichnos, 3, 265-272.

Chamberlain, C.K. 1975. Recent lebensspuren in non-marine environments. In: The Study of Trace Fossils (Ed. R.W. Frey). Springer Verlag, New York, 431-458.

Charbonneau, P. and Hare, L. 1998. Burrowing behaviour and biogenic structures of mud dwelling-insects. Journal of the North American Benthological Society, 17, 239249.

Crimes, T. P, García Hidalgo, J. F. and Poire, D. G. 1992. Trace fossils from Arenig flysch sediments of Eire and their bearing on the early colonisation of deep seas. Ichnos, 2, 61-77.

Crusafont, M., Villatta, J.F. y Julivert, M. 1966. Notas sobre la estratigrafía y paleontología de la Cuenca de Calatayud-Teruel. Notas y Comunicaciones IGME, 19, 53-76.

D'Alessandro, A. and Bromley, R. G. 1987. Meniscate trace fossils and the Muensteria-Taenidium problem. Palaeontology, 30, 743-763.

Domínguez Alonso, P. y Coca Abia, M.M. 1998. Nidos de avispas minadoras en el Mioceno de Tegucigalpa (Honduras, América Central). Coloquios de Paleontología, 49, 93-114.

Donovan, S. K. 1994. Insects and arthropods as trace-makers in non-marine environments and palaeoenvironments. In: The Palaeobiology of Trace Fossils (Ed. S. K. Donovan). John Wiley \& Sons, Chichester, 200-220.

Ducreux, J.L., Billaud, Y. et Truc, G. 1988. Traces fossiles d'insectes dans les paleosols rouges de l'Eocene supérieur du nord-est du Massif Central français: Celliforma arvernensis ichnosp. nov. Bulletin de la Société géologique de France, 4, 167-175.

Edwards, N., Jarzembowski, E. A., Pain, T. and Daley, B. 1997. Coccon-like trace fossils from the lacustrinepalustrine Bembridge Limestone Formation (Late Eocene), Southern England. Proceedings of the Geologists' Association, 109, 25-32.

Eickwort, G.C. 1969. Tribal positions of western hemisphaere green seat bees, with comments on their nest architecture (Hymenoptera: Halictidae). Annals of the Entomological Society of America, 62, 652-661.

Eickwort, G.C. and Sakagami, S.F. 1979. A classification of nest architecture of bees of the tribe Augochlorini (Hymenoptera, Halictidae) with the description of a Brazilian nest of Rhinocorynura inflaticeps. Biotropica, 11, 28-37.

Ekdale, A. A. and Lewis, D. W. 1991. Trace fossils and paleoenvironmental control of ichnofacies in a late Quaternary gravel and loess fan delta complex, New Zealand. Palaeogeography, Palaeoclimatology, Palaeoecology, 81, 253-279.

Ekdale, A. A., Bromley, R. G. and Pemberton, G. S. 1984. Ichnology: the use of trace fossils in sedimentology and stratigraphy. Society of Economic Paleontologists and Mineralogists, Short Course, 15, 1-317.

Elliott, D. K. and Nations, J. D. 1998. Bee burrows in the Late Cretaceous (late Cenomanian) Dakota Formation, northeastern Arizona. Ichnos, 5, 243-253.
Fedonkin, M. 1985. Paleikhnologiya vendskich Metazoa [Paleoichnology of the Vendian Metazoa]. In: Vendskaya Sistema 1. Paleontologiya (Eds. B.S. Sokolov and A.B. Iwanowskij). Nauka, Moscow, 112-117.

Frey, R. W., Curran, A. H. and Pemberton, G. S. 1984. Tracemaking activities of crabs and their environmental significance: the ichnogenus Psilonichnus. Journal of Paleontology, 58, 511-528.

Fürsich, F. T. 1973. A revision of the trace fossils Spongeliomorpha, Ophiomorpha and Thalassinoides. Neues Jahrbuch für Geologie und Paläontologie, Monatshefte, 1972, 719-735.

Fürsich, F.T. 1981. Invertebrate trace fossils from the Upper Jurassic of Portugal. Comunicaçoes dos Serviços Geológicos de Portugal, 67, 153-168.

Fürsich, F. T., Kennedy, W. J. and Palmer, T. J. 1981. Trace fossils at a regional discontinuity surface: the Austin/Taylor (Upper Cretaceous) contact in central Texas. Journal of Paleontology, 55, 537-551.

Genise J.F. and Bown T.M. 1994. New Miocene scarabeid and hymenopterous nests and Early Miocene (Santacrucian) paleoenvironments, Patagonian Argentina. Ichnos, 3, 107-117.

Genise, J.F. and Bown, T.M. 1996. Uruguay Roselli 1938 and Rosellichnus n. ichnogenus: two ichnogenera for clusters of fossil bee cells. Ichnos, 4, 199-217.

Genise, J.F. and Hazeldine, P.L. 1998. The ichnogenus Palmiraichnus Roselli for fossil bee cells. Ichnos, 6, 151-166.

Hasiotis S.T. and Bown T.M. 1992. Invertebrate trace fossils: the backbone of continental ichnology. In: Trace Fossils (Eds. C.G. Maples and R.R. West). Short Courses in Paleontology, 5, 64-104. Paleontological Society, Knoxville, Tennessee.

Heer, O. 1877. Flora Fossilis Helvetiae. Vorweltliche Flora der Schweiz. J. Wurster and Comp. Zürich, 182 pp.

Houston, T.F. 1987. Fossil brood cells of Stenotridid bees (Hymenoptera, Apoidea) from the Pleistocene of South Australia. Transactions of the Royal Society of South Australia, 111, 93-97.

Keighley, D. G. and Pickerill, R. 1994. The ichnogenus Beaconites and its distinction from Ancorichnus and Taenidium. Palaeontology, 37, 305-337.

Książkiewicz, M. 1968. O niektórych problematykach z fliszu Karpat polskich (częś́ III) [On some problematic organic traces from the Flysch of the Polish Carpathians (part III)]. Rocznik Polskiego Towarzystwa Geologicznego, 38, 3-17.

Larsen, E.B. 1936. Biologische Studien über die tunnelgrabenden Kafer auf Skallingen. Videnskabilige Meddelelser fra Dansk Naturhistorisk Forening, 100, 1232.

McCall, P.L. and Tevesz, M.J.S. 1982. The effect of benthos on physical properties of fresh water sediments. In: Animal-Sediment Relations (Eds. P.L. McCall and M.J.S. Tevesz). Plenum Press, New York, 105-176.

Metz, R. 1990. Tunnels formed by mole cricket (Orthoptera: Gryllotalpidae): paleoecological implications. Ichnos, 1, 139-141.

Metz, R. 1993. A new ichnospecies of Spongeliomorpha from the Late Triassic of New Jersey. Ichnos, 2, 259-262. 
Minkiewicz, R. 1934. Les Pampilides à nide fixe et ceux à nidmomentené (Etude d'éthologie comparée). Polskie Pismo Entomologiczne, 13, 43-60.

Oliver, D.R. 1971. Life history of the Chironomidae. Annual Review of Entomology, 16, 211-230.

Olmo, P. del, Hernández, A. y Aragonés, E. 1983. Mapa geológico de España. Escala 1:50000. Explicación de la hoja n. 437(25-17), Ateca. IGME ed., 67 pp.

OrXowski, S. 1968. Kambr antykiliny Xysogórskiej Gór Swiętokrzyskich (Cambrian of Lysogóry Anticline in the Holy Cross Mountains). Biuletyn Geologiczny, 10, 195 221.

OrKowski, S. and Zylińska, A. 1996. Non-arthropod burrows from the Middle and Late Cambrian of the Holy Cross Mountains, Poland. Acta Palaeontologica Polonica, 41, 385-409.

Pemberton, G. S. and Frey, R. W. 1982. Trace fossil nomenclature and the Planolites-Palaeophycus dilemma. Journal of Paleontology, 56, 843-881.

Pfeiffer, H. 1968. Die Spurenfossilien des Kulms (Dinant) und Devons der Frankenwalder Querzone (Thuringen). Jahrbuch der Geologie, 2, 651-717.

Ratcliffe B.C. and Fagerstrom J.A. 1980. Invertebrate lebenspuren of Holocene flood plains: their morphology, origin and paleoecological significance. Journal of Paleontology, 54, 614-630.

Retallack G.J. 1984. Trace fossils of burrowing beetles and bees in an Oligocene paleosol, Badlands National Park, South Dakota. Journal of Paleontology, 58, 571-592.

Rodríguez-Aranda, J.P. 1992. Significado de bioturbaciones en un medio evaporítico continental (Mioceno de la Cuenca de Madrid). Geogaceta, 12, 113-115.

Rodríguez-Aranda, J.P. and Calvo, J.P. 1998. Trace fossils and rhizoliths as a tool for sedimentological and palaeoenvironmental analysis of ancient continental evaporite successions. Palaeogeography, Palaeoclimatology, Palaeoecology, 140, 383-399.

Roselli, F.L. 1987. Paleoicnología. Nidos de insectos fósiles de la cobertura Mesozoica del Uruguay. Publicaciones del Museo Municipal de Nueva Palmira, 1, 1-56.
Sakagami, S.F. and Michener, C.D. 1962. The Nest Architecture of the Sweat Bees (Halictinae). The University of Kansas Press, Knoxville, 135 pp.

Saporta, G. de. 1887. Nouveaux documents relatifs aux organismes problématiques des anciennes mers. Bulletin de la Société géologique de France (série 3), 15, 286302.

Schlirf, M, Uchman, A. and Kümmel, M. (in press). Upper Triassic (Keuper) non-marine trace fossils from the Haßberge region (Franconia, southern Germany). Paläontologische Zeitschrift.

Stanley, K.O. and Fagerstrom, J.A. 1974. Miocene invertebrate trace fossils from a braided river environment, western Nebraska, U.S.A. Palaeogeography, Palaeoclimatology, Palaeoecology, 15, 63-82.

Squires, R.L. and Advocate, M.D. 1984. Meniscate burrows from Miocene lacustrine-fluvial deposits, Diligencia Formation, Orocopia Mountains, southern California. Journal of Paleontology, 58, 593-597.

Thackray, G. D. 1994. Fossil nests of sweat bees (Halictinae) from a Miocene paleosol, Rusinga Island, western Kenya. Journal of Paleontology, 68, 795-800.

Uchman, A. 1995. Taxonomy and palaeoecology of flysch trace fossils: the Marnoso-arenacea Formation and associated facies (Miocene, Northern Apennines, Italy). Beringeria, 15, 1-115.

Uchman, A. 1998. Taxonomy and ethology of flysch trace fossils: a revision of the Marian Książkiewicz collection and studies of complementary material. Annales Societatis Geologorum Poloniae, 68, 105-218.

Vialov, O. S. 1962. Problematica of the Beacon Sandstone at Beacon Height West, Antarctica. New Zealand Journal of Geology and Geophysics, 5, 718-732.

Walshe, B.M. 1951. The feeding habits of certain chironomid larvae (subfamily Tendipedinae). Proceedings of the Zoological Society of London, 121, 63-89.

Wetzel, A. 1983. Biogenic structures in modern slope to deep-sea sediments in the Sulu Sea Basin (Philippines). Palaeogegraphy, Palaeoclimatology, Palaeoecology, 42, 285-304. 